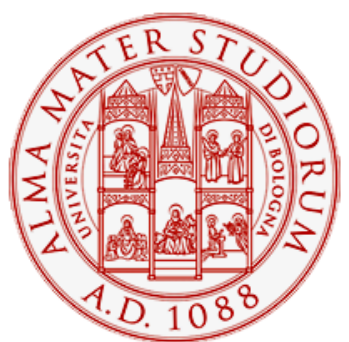

Alma Mater Studiorum - Università di Bologna DEPARTMENT OF ECONOMICS

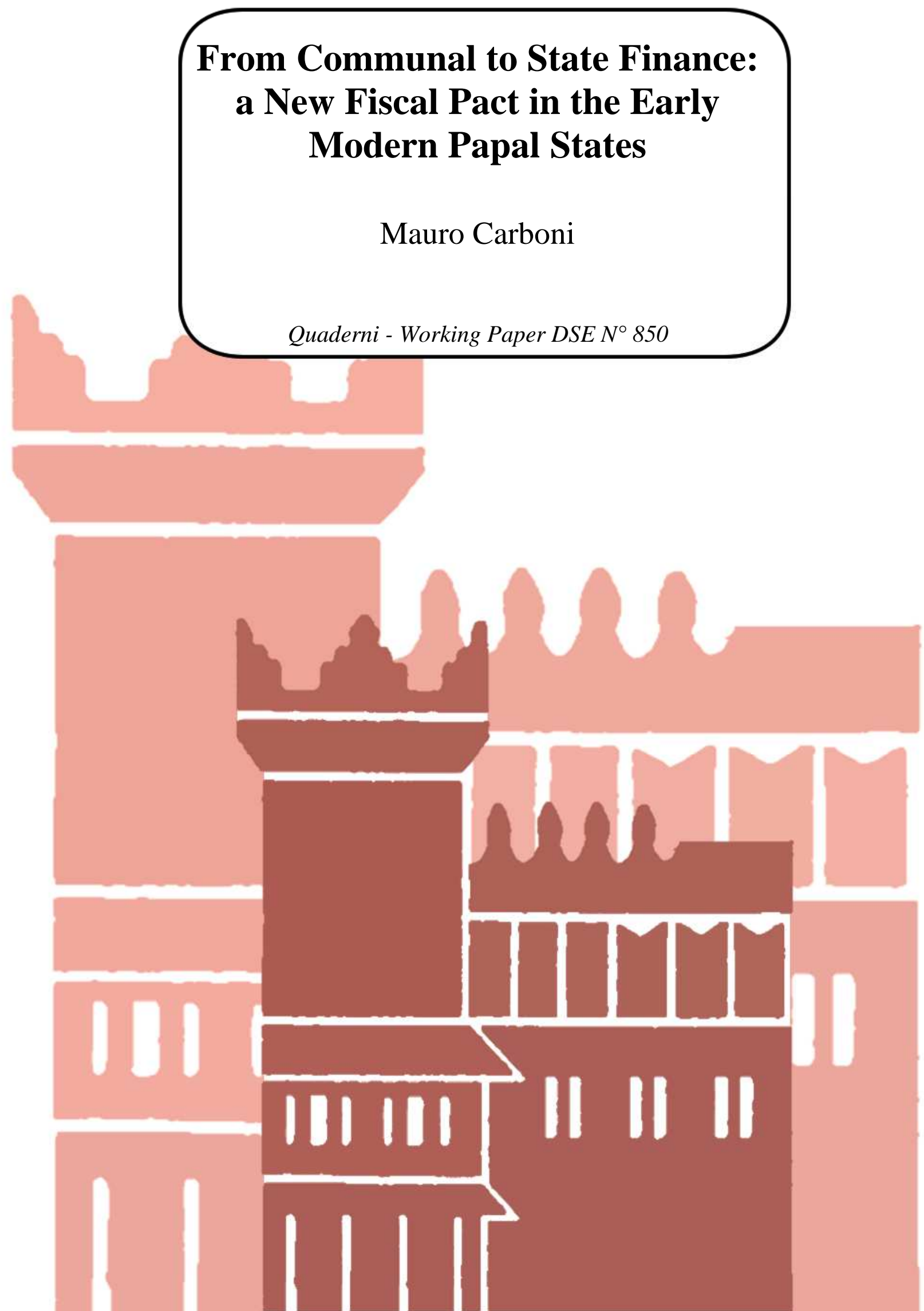




\title{
From Communal to State Finance: a New Fiscal Pact in the Early Modern Papal States
}

\begin{abstract}
Mauro Carboni ${ }^{1}$
Keywords: Papal States, financial revolution, taxation, public debt

JEL Codes: N23, N43

Abstract :

State building and state competition during the $16^{\text {th }}$ century triggered a creative moment in the history of public finance. Recent scholarship has clearly identified the Papal States and their communities as active participants both in the state building process and the reorganization of public finance. Banking on a wealth of fiscal records, it is argued that Papal authority succeeded in forging a new fiscal pact - which lasted over two centuries - between central and local authorities. Blending conservatism and innovation the papacy promoted a contractual approach: local powers were granted a large degree of autonomy in selecting fiscal instruments, the types of wealth to be taxed and the means of collecting resources, while the Apostolic Chamber secured both the control of a growing portion of the provinces' fiscal income as well as access to a pool of financial resources at a rapidly declining cost.

Università di Bologna

Dipartimento di Scienze Economiche

mauro.carboni@unibo.it
\end{abstract}

1. Recent scholarship has clearly identified the Papal States and its larger communities as active and creative participants both in the European state building process and in the financial revolution of the early modern period. In establishing firmer control over territories in Central Italy the Papacy was able to bank on Italian city republics tradition, which Popes managed to update and recast in the context of a territorial state. The impersonal character attributed to the state by republican regimes was well suited to the Papacy, as an electoral monarchy.

\footnotetext{
${ }^{1}$ Paper presented at international Colloque « Ressources publiques et construction étatique en Europe. Fiscalité et dette publique, XIIIe-XVIIIe siècle », held at the Université Paris 1 Panthéon-Sorbonne and Ministères èconomique et financier, 2-3 July 2012.
} 
This paper will argue that the $16^{\text {th }}$ century Papacy succeeded in forging a new fiscal pact between central and local authorities. Blending conservatism and innovation the papacy promoted a contractual approach: central authority established its exclusive right to impose tributes while local powers were granted a large degree of autonomy in selecting fiscal instruments, the types of wealth to be taxed and the means of collecting resources.

From the mid- $15^{\text {th }}$ century the Papacy was engaged in two difficult intertwined struggles: to consolidate its Italian domains - threatened by external aggression as well as internal anarchy - and to shore up its finances sapped by involvement in costly wars and the drying up of the flow of "spiritual" revenues from all over Catholic Europe. The Protestant storm added dramatic urgency to an already critical situation. Papal finances emerged from this crisis largely transformed: although "spiritual" revenues continued to provide a contribution to the treasury, it was temporal revenues that took the lead. Fiscal income from Papal territories increased over three times during the $16^{\text {th }}$ century, surging from about 330,000 silver scudi in 1526 to 1,045,000 scudi in 1599. Fiscal receipts more than doubled again in the first half of the $17^{\text {th }}$ century, reaching about 2.2 million silver scudi in 1657, to stabilize afterwards around that figure. Compared to overall Papal income, the contribution brought in by fiscal receipts increased markedly from little more than half (55\% in 1526) to nearly nine tenths by the early 1670 s (Tab. 1).

Tab. 1 - Fiscal income and public debt in the Papal States (1526-1672)

\begin{tabular}{|c|c|c|c|c|}
\hline \multirow[t]{2}{*}{ Year } & \multicolumn{2}{|c|}{$\begin{array}{l}\% \text { of total } \\
\text { income }\end{array}$} & Total revenues & Overall public debt \\
\hline & scudi & & scudi & Scudi \\
\hline 1526 & 329,986 & 55.4 & 594,986 & $2,796,210$ \\
\hline 1576 & 706,426 & 74.7 & 945,315 & $7,040,650$ \\
\hline 1592 & $1,181,131$ & 73.8 & $1,601,195$ & $10,520,678$ \\
\hline 1619 & $1,374,520$ & 76.8 & $1,790,520$ & $15,975,623$ \\
\hline 1657 & $2,222,003$ & 82.8 & $2,684,515$ & $30,723,339$ \\
\hline 1672 & $2,243,441$ & 88.3 & $2,541,039$ & $37,784,307$ \\
\hline
\end{tabular}


The domains in Central Italy shouldered the largest share of the growing tax burden. For instance, between 1576 and 1678 the three northern provinces of Umbria, Marca and Romagna provided roughly two fifths of papal temporal revenues, but while their share remained fairly stable - actually dropping a little from $39.6 \%$ to $38.1 \%$ - yet the actual sums raised from their communities expanded in a spectacular fashion, posting a threefold leap: from 295,000 scudi to 969,000 scudi (Tab. 2).

Tab. 2 - State revenues raised by the northern provinces of the Papal States

\begin{tabular}{|r|r|r|r|r|r|r|}
\hline Year & $\begin{array}{r}\text { Umbria } \\
\text { (scudi) }\end{array}$ & $\begin{array}{r}\text { \% of state } \\
\text { revenues }\end{array}$ & $\begin{array}{r}\text { Marca } \\
\text { (scudi) }\end{array}$ & $\begin{array}{r}\text { \% of state } \\
\text { Revenues }\end{array}$ & $\begin{array}{r}\text { Romagna } \\
\text { (scudi) }\end{array}$ & $\begin{array}{r}\text { \% of state } \\
\text { Revenues }\end{array}$ \\
\hline 1576 & 68,144 & 9.6 & 137,609 & 19.4 & 89,436 & 12.6 \\
\hline 1589 & 107,361 & 9.3 & 162,239 & 14.1 & 139,436 & 12.1 \\
\hline 1619 & 133,879 & 9.6 & 237,819 & 17.2 & 150,832 & 10.9 \\
\hline 1657 & 240,766 & 10.8 & 405,397 & 18.2 & 220,369 & 9.9 \\
\hline 1678 & 251,645 & 9.9 & 394,170 & 15.5 & 323,501 & 12.7 \\
\hline
\end{tabular}

2. As Popes succeeded to establish stricter control over their territories in Central Italy, the system of taxation was subject to considerable revision, designed to extract more resources, to establish centrally controlled bureaucratic procedures and to introduce a degree of equality and uniformity. However, efforts did not meet with equal success in the three areas.

From the early decades of the $16^{\text {th }}$ century it was apparent a concerted effort at establishing administrative rights, at asserting fiscal sovereignty and at casting a more effective fiscal net across Papal lands. Since nearly all taxation was administered and exacted at the municipal level, existing fiscal rights and procedures had to be 
documented and, possibly, revised. Roughly between the 1530s and the 1550s local authorities across the land produced and submitted a tremendous wealth of descriptions of existing municipal rights and practices. For instance on 10 March 1555 the Senate of Bologna submitted to the approval of Pope Julius III a thorough documentation of all tributes levied in the city and the territory subject to it. Origins and destination of each tribute were spelled out as well as how it was assessed and collected.

Existing systems of municipal taxation were largely left in place to cover for the costs of local administrations. But the introduction of new taxation as well as additions to existing dues became the exclusive preserve of the sovereign. In practice local boards were subordinated, without exception, to state authority on fiscal matters.

Most new taxation took the form of centrally controlled state-wide tributes. Quite frequently new taxes started as extraordinary levies, but once introduced most new tributes tended to become permanent. The model was the so called Sussidio Triennale, issued by Pope Paul III as a temporary - three year - tribute in 1543, then twice reiterated and finally made permanent in 1552, to become popularly known as eternale. Between 1529 and 1600 no less than nineteen new state tributes were introduced. Most of these were lesser taxes, such as danni dati (proceeds of justice), archivio (public records), legna (wood), carte da gioco (cards), pesi e misure (weights and measures), pelli e cuoi (leatherworks) and so on. Only a handful - five had in practice a major financial impact: Triennale (1543, real estate), quattrino (1555, meat), cavalli morti (1559, subsidy for the army), foglietta (1588, wine), galere (1588, subsidy for the upkeeping of the fleet). At the end of the $16^{\text {th }}$ century the combined yield of these five tributes represented almost $50 \%$ of temporal revenues.

Fiscal income posted remarkable increases across Papal territories from the early decades of the $16^{\text {th }}$ century to the second half of the $17^{\text {th }}$ century, but this expansion conceals two very different trends: on the one hand the yield of local dues 
stagnated or barely moved, on the other the yield of state tributes spiralled upward. Evidence from surviving balance sheets of the main communities of the Romagna confirms that in the central decades of the 16th century a remarkable shift took place: revenues raised in the towns of Imola, Ravenna, Forlì and Cesena expanded at a very fast pace. (Fig. 1). The lion's share of this increase however went to benefit only state coffers, in fact on average the share of state revenues jumped from less than half to about four fifths (Fig. 2).

More favorable to local authorities was the situation in Bologna, which was able to retain greater autonomy, yet the long-term trend was hardly different. Between the 1540s and the 1590s the share of fiscal receipts claimed by state climbed from less than $30 \%$ to $50 \%$.

Fig. 1- Total revenues collected in Imola, Forlì, Ravenna and Cesena, 1520-1660

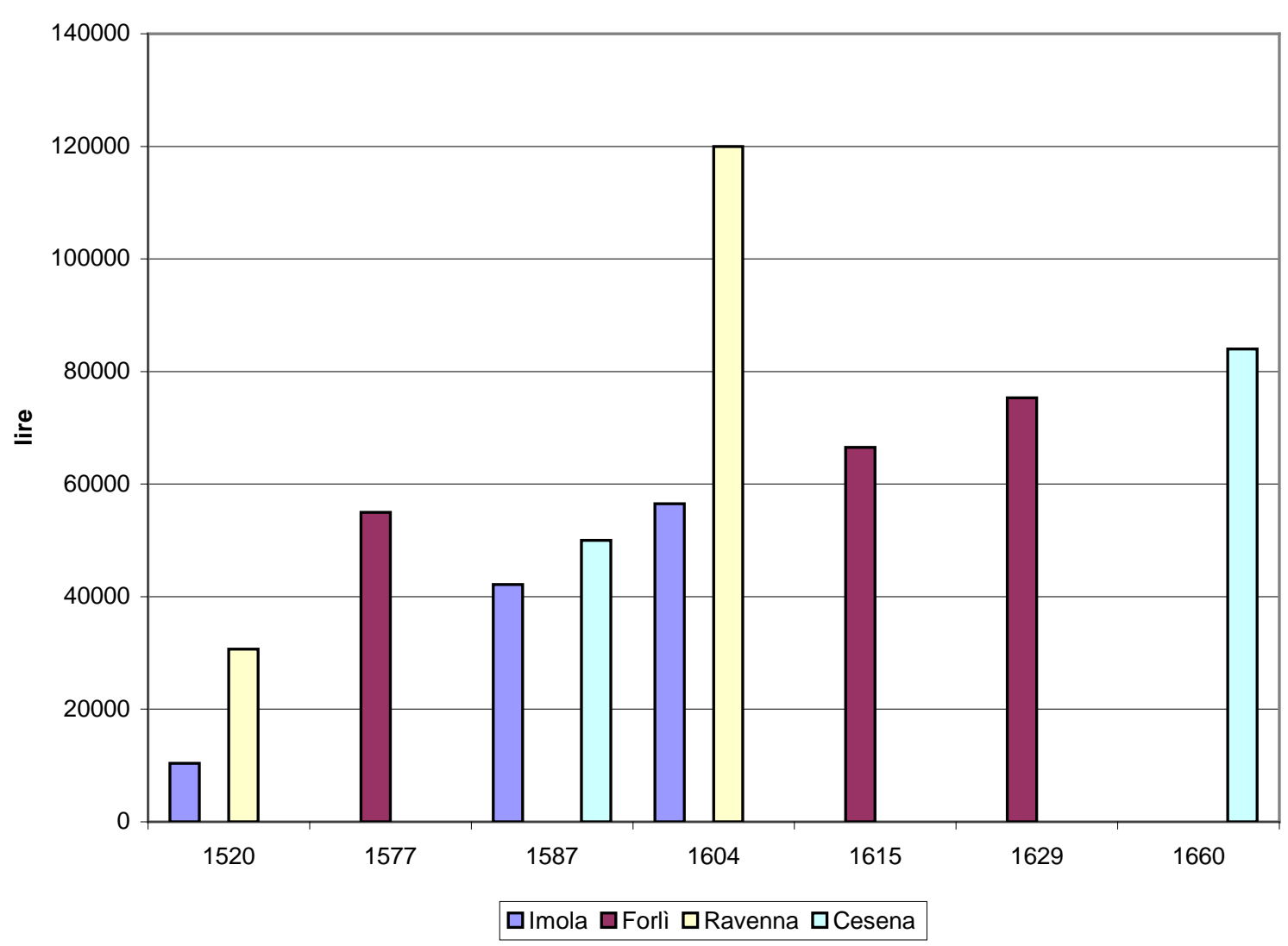


Fig. 2 - Share of state revenues in Imola, Forlì, Ravenna, Cesena and Bologna, 1520-1660

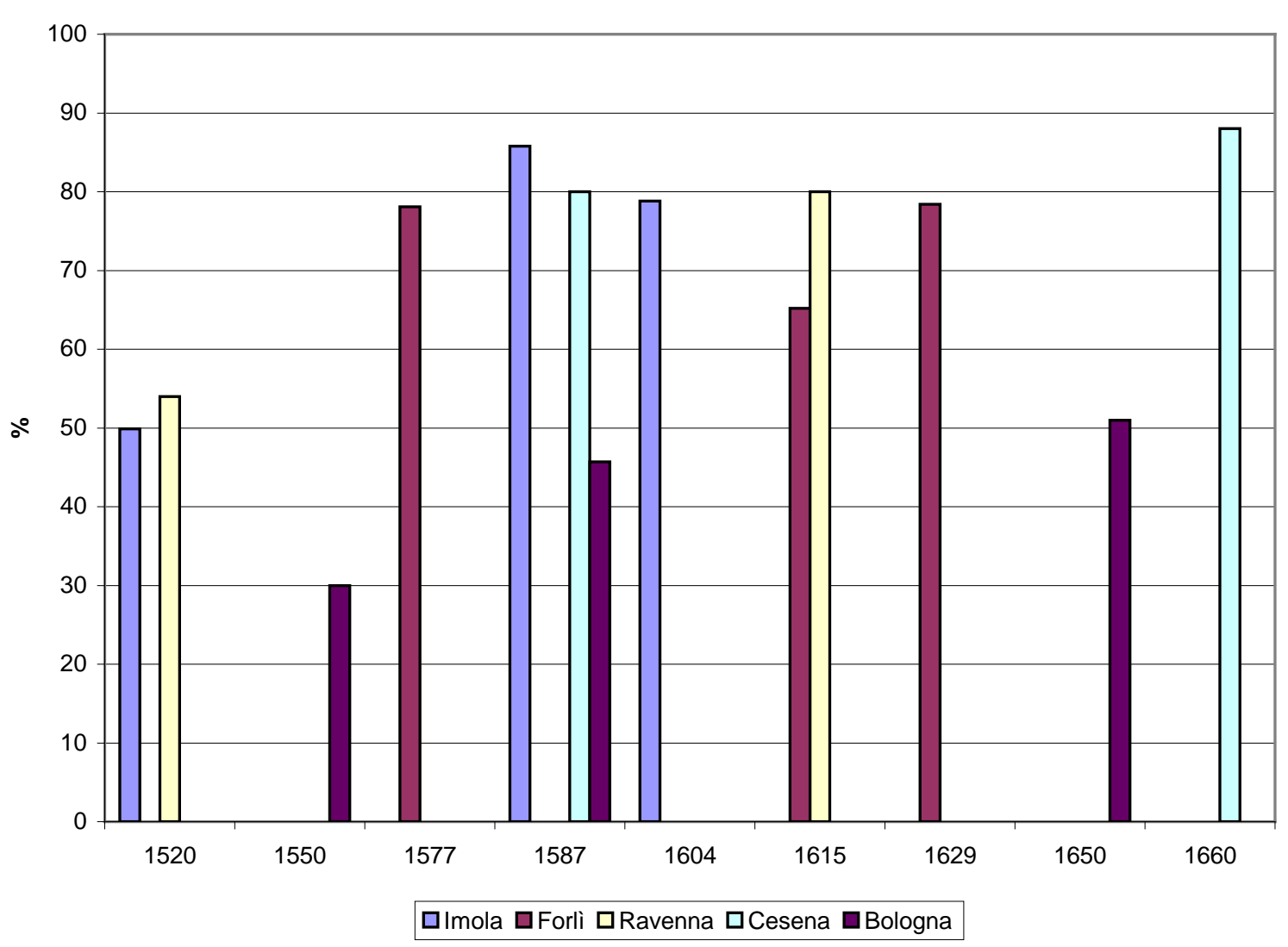

The issuance of the De bono regimine bull and the establishment of the Congregazione del Buon Governo in 1592 completed the process of subordination of local to state government. Communities - with very few exceptions - had to submit every year the tavola (a provisional budget of income and expenditures) and were subject to authorization on part of the Congregazione. In this way the central government was able to monitor the actual flow of fiscal resources, to control municipal indebtdness and, possibly, to discourage financial malpractices at the local level.

To handle fiscal resources the Apostolic Chamber relied on a network of provincial treasuries, who were farmed out to merchant bankers. Treasurers guaranteed both a steady flow of resources and payments in advance. In the main 
local treasurers did not collect taxes but relied on an indirect system: subjects paid dues to local authorities who in turn paid taxes to provincial treasurers, who were responsible for handling money on behalf of the Apostolic Chamber.

3. Popes recognized the composite nature of the realm they presided and the limits of coercive options. In the main they preferred to advance their sovereignty by consent and cooperation through the signing of pacts and agreements rather than by the exercise of dictatorial power. Acceptance of Papal sovereignty did not translate in the dismantling of local governing practices but rather in their updating. In practice Papal absolutism was "limited" and required the active cooperation of local élites.

New state taxation aimed, at least in theory, at introducing relevant innovations, the most important of which was universal application to territories as well as individuals, regardless of status and privileges. In practice application fell considerably short of that end: a universal system of taxation upon territories as well as an equal division of the tax burden between economic activities and social groups failed to emerge. Instead growth of fiscal pressure went hand in hand with Papal ability to forge alliances with local elites and the mosaic pattern of immunities and privileges was not rolled back. The well known sussidio triennale (1543), commonly heralded by historians of Papal finance as the most significant attempt to introduce a new and uniform tribute across the land, provides an exemplary tale. Although conceived as a model state tax, affecting all communities without exceptions and exemptions, its application was subject to negotiations with local authorities, which managed to reduce its weight and, more important, won the right to assess and levy the tribute as they saw fit. Each community had to pay a precise share of the burden but could choose how to apply the new tax. For examples most communities in Romagna placed the burden on real estate, while Bolognese authorities opted to shield landowners and to collect it by way of various duties instead (such as grain, gates and silk). 
In its relentless quest to extract ever more resources from its domains the Papacy accepted the mediation of local authorities, leaving actual implementation to local boards. The contractual nature of the relations between Popes and the various components of the state is evident from the ability of communities on assuming responsibilities for the assessment and collection of taxes by means they thought fit. Nowhere this pattern is more obvious than in Bologna, the second largest city of the Papal States. Annexed in 1506, Bologna was able to secure terms, which granted civic authorities considerable latitude for independent action and guaranteed that Papal will would be mediated through city offices. Deference and loyalty to the Pope/king paid handsome dividends.

Not surprisingly fiscal geography mirrored power relations within the state, among and within communities, rather than taxable wealth. The triennale was assessed for 62,000 scudi in the Marca but for 42,000 in Umbria, despite the fact that the latter had more inhabitants (300,000 against 280,000) and an overall more prosperous urban economy. Even more spectacular the advantage enjoyed by the Legazione of Bologna, which was charged just 12,000 scudi, despite a population in excess of 200,000. Within provinces differences could be equally disturbing: in Romagna Faenza, Forlì and Cesena paid 5,060, 4,370 and 6,095 respectively although both their economic conditions and overall population were roughly the same. Substantial differences in treatment characterized urban and rural areas, as well as different social groups within cities. In the main country folks and urban lower classes ended up shouldering most of the burden.

4. As temporal revenues soared so did the ability of the Apostolic Chamber to mobilize additional financial resources through borrowing. From the mid- $16^{\text {th }}$ century onward the largest single charge on Papal income was the servicing of the debt, which at mid- $17^{\text {th }}$ century absorbed a about $60 \%$ of total income collected.

The new system of Papal debt proved to be remarkably efficient. It generated an ever larger number of issues which were run separately. In little more than a 
century and a half the Treasury had authorized 187 separate issues. The overall debt increased at a rapid pace throughout the $16^{\text {th }}$ and $17^{\text {th }}$ centuries. From 1526 to 1599 Papal funded debt more than tripled jumping from 3.3 to 11.6 million scudi. It more than tripled again during the $17^{\text {th }}$ century reaching 39.7 million scudi in 1678 .

Tab. 3 - Papal States overall debt and servicing costs, 1526-1678.

Debt service

Total Debt

scudi

$2,796,210$

$7,040,650$

$11,665,223$

$15,975,623$

$30,723,339$

$39,675,197$

debt/income

1526

1576

1619

1657

1678

Establishing credibility meant winning and mantaining the trust of lenders. And the emission of Papal funded debt (mont)i was tailored to that end. As debtors Popes were readier than other monarchs to adopt policies conducive to trust: providing binding sets of guarantees, limiting discretion and accepting responsibility for financial obligations incurred by their predecessors. The contractual limits to Papal power were reassuring to perspective creditors and enhanced rather than hinder Popes' ability to borrow. Investors' trust in Papal debt is illustrated by the Apostolic Chamber's ability to borrow very large sums of money at sharply declining interest rates. Between mid- $16^{\text {th }}$ century and mid- $17^{\text {th }}$ century nominal interest paid on redeemable bonds halved from $8 \%$ to $4 \%$. Returns were further cut to just $3 \%$ with the large concentration of a jumble of different issues into the St. Peter bonds between 1684 and 1686. Considering that bonds traded regularly above par on the secondary market, the rate of returns investors were willing to accept was even lower, a clear indication that Papal government had fully succeeded in asserting itself as one of the most reliable borrower in Europe. Indeed in the second half of the $17^{\text {th }}$ century 
the Papacy was able to raise money at less than half the cost shouldered by contemporary French and English monarchs.

This said it has to be noticed that Papal financial needs rose faster than fiscal income and despite the declining cost of borrowing the weight of debt servicing rose dangerously, absorbing two thirds of revenues by the 1670s.

5. Success in expanding and modernizing state finance in the $16^{\text {th }}$ century came at a price. It underscored the contractual nature of relations. Papal predicament was that the cornerstone of the new system - close cooperation with local élite - stood in the way of further advances. Municipal as well as class privilege persisted. Papal attempts to widen the state fiscal base and to introduce more equitable forms of taxation made little headway, precisely because they required the coopeartion of the very groups that had most to lose from fiscal reforms. By the mid- $17^{\text {th }}$ century, as the system approached its upper limits the contractual character of Papal power ceased to be an asset to become an insuperable barrier to both greater financial integration and economic development.

Main references:

M. Caravale (1974), La finanza pontificia nel Cinquecento. Le province del Lazio, Naples.

M. Carboni (1995), Il debito della città. Mercato del credito, fisco e società aBologna fra Cinque e Seicento, Bologna.

M. Carboni (2008), La finanza pubblica a Bologna in età moderna, in A. Prosperi (ed), Bologna nell'età moderna (secoli XVI-XVIII). I. Istituzioni, forme del potere, economia e società, Bologna.

C. Casanova (1981), Comunità e governo pontificio in Romagna in età moderna, Bologna.

F. Colzi (1999), Il debito pubblico del Campidoglio. Finanza comunale e circolazione dei titoli a Roma fra Cinque e Seicento, Naples.

A. Gardi (1986), La fiscalità pontificia fra Medioevo ed età moderna, in “Società e Storia”, 33.

A.Gardi (1994), Lo stato in provincia. L'amministrazione della Legazione di Bologna durante il regno di Sisto V (1585-1590), Bologna.

M.C. Giannini (2003), L'oro e la tiara. La costruzione dello spazio fiscale italiano della Santa Sede (1560-1620), Bologna.

F. Guidi Bruscoli (2007), Papal banking in Renaissance Rome, London.

R. Masini (2005), Il debito pubblico pontificio a fine Seicento. I Monti camerali, Roma.

P. Partner (1999), The Papacy and the Papal States, in R. Bonney (ed.), The Rise of the Fiscal State in Europe, c. 1200-1815, Oxford. 
L. Pezzolo (1999), Government debts and trust. French Kings and Roman Popes as borrowers, 1520-1660, in "Rivista di Storia Economica”, XV, pp. 233-261.

F. Piola Caselli (2008), Government debts and financial markets in Europe, London.

E. Stumpo (1985), Il capitale finanziario a Roma fra Cinque e Seicento. Contributo alla storia della fiscalità pontificia in età moderna (1570-1660), Milan.

B. Zenobi (1976), Ceti e poteri nella Marca pontificia, Bologna. 


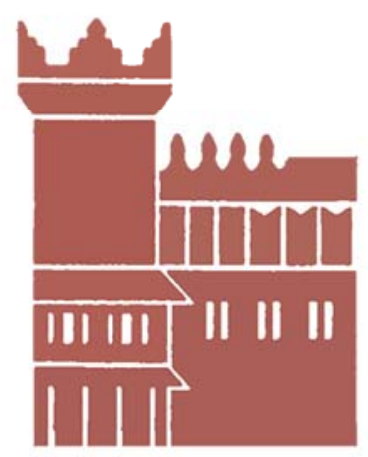

Alma Mater Studiorum - Università di Bologna DEPARTMENT OF ECONOMICS

Strada Maggiore 45

40125 Bologna - Italy

Tel. +39051 2092604

Fax +390512092664

http://www.dse.unibo.it 